\title{
Explaining verbal humour to the audience - The case of Plautine neologisms
}

\author{
Joanna Pieczonka
}

(University of Wrocław)

\begin{abstract}
Plautus frequently uses new word formations to increase the comicality of his plays. Such facetious neologisms must have been understood by the audience, otherwise the jokes in the comedies would not have made any sense. However, there are a few passages in which the author explains his newly-coined lexemes through the words of the characters in the plays. This article analyses these utterances, trying to explain why Plautus decided to unveil his process of word creation in these particular places, what function the neologisms have in the dramatic text, how the writer denotes and describes the neologisms, and whether it helps spectators to recognise and appreciate his verbal humour. Most of these passages concern legal neologisms (intestabilis - PI. Cur. 30-32; parenticida - Epid. 349-351; rabo - Truc. 687-690) and one of them contains a comic name/title (Subballio - Ps. 607-609). The playwright explains the etymology of the new Latin words or shows how he has adapted Greek wordplay (arrabo-rabo) for Roman spectators. These riddle-like explanations are composed following the pattern of identification motifs. Their main goal is to intensify the power of the jokes and their impact on the audience.
\end{abstract}

\section{Keywords}

Plautus; new words; compound word-formations; legal neologisms; identification motifs 
Fingere verba seems to be a frequent practice of Plautus, who uses language to increase the comicality of his plays. The author "achieves considerable diversity" 1 in creating neologisms and in their use in different dramatic contexts. Although "a good number of Plautine neologisms remains unclassified as yet", ${ }^{2}$ there have been some attempts to categorise them, e.g. by J. Peter Stein (1971) or Michael Fontaine (2010). ${ }^{3}$ Stein, in his article Compound Word Coinages in the Plays of Plautus, gives examples of many different ways in which the comic writer employs neologisms: (1) similar words are piled up (this is a device called accumulatio), ${ }^{4}(2)$ a neologism may be the strongest element, placed at the

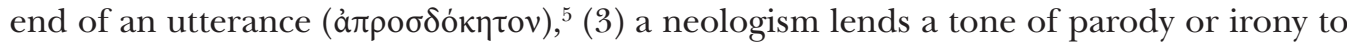
the statement, ${ }^{6}(4)$ a neologism may be used as a mocking epithet, ${ }^{7}(5)$ some neologisms reveal or emphasise an important aspect of an action, motif or character, ${ }^{8}$ and (6) a neologism underlines emotions. ${ }^{9}$ New-coined words may be found in the roles of various characters ${ }^{10}$ and they comprise many parts of speech (nouns, adjectives, verbs, adverbs and even pronouns). ${ }^{11}$ That notwithstanding, we have to admit that Plautus invented new words for their comic effect and if they were to please and amuse the audience they had to be understood by the spectators, otherwise the jokes would not have made any sense in the comedies. However, there are a few passages in which the author explains his newly-coined lexemes through the words of the characters in the plays. In my article I wish to examine these utterances to check why Plautus discloses his process of word formation in these particular places, how he describes and terms his neologisms, what impact they have on the meaning of the whole passage and finally whether this Plautine frankness helps the spectators to perceive and appreciate his verbal innovations and wordplays.

1 Stein (1971: p. 601).

2 Stein (1971: p. 601).

3 Fontaine (2010) tries to classify neologisms within the categories of stylistic devices.

4 E.g. Pl. Mil. 191-192: domi habet animum falsiloquum, falsificum, falsiiurium,/ domi dolos, domi delenifica facta, domi fallacias; Most. 356: ubi sunt isti plagipatidae, ferritribaces viri; Rud. 652: legerupa inpudens, inpurus, inverecundissumus; Trin. 1020-1021: †Truthus† fuit, Cerconicus, Crinnus, Cercobulus, Collabus,/ oculicrepidae cruricrepidae, ferriteri mastigiae.

5 E.g. Pl. Curc. 76-77: anus hic solet cubare custos ianitrix./ nomen Leaenaest, multibiba atque merobiba; Rud. 636: ut tibi ulmeam uberem esse speres virgidemiam; Cas. 974: Quid agis, dismarite? (...)

6 E.g. Pl. Trin. 820-821: Salsipotenti et multipotenti Iovi' fratri et Neri Neptuno/ laetu' lubens laudis ago et gratis gratiasque habeo et fluctibu' salsis; Ps. 286-288: (...) si amabas, invenires mutuom,/ ad danistam devenires, adderes faenusculum,/ surruperes patri. (...); Mil. 42-45: (...) Memini: centum in Cilicia/ et quinquaginta, centum in Scytholatronia,/ triginta Sardos, sexaginta Macedones / sunt homines quos tu occidisti uno die.

7 E.g. Pl. Poen. 506: sicut ego hos duco advocatos, homines spissigradissumos; Poen. 586: hodie iuris coctiores non sunt qui lites creant.

8 E.g. Pl. Am. 59: faciam ut commixta sit; <sit> tragico[co]moedia; Rud. 652: legerupa inpudens, inpurus, inverecundissumus (about the pimp); Cur. 444: Rhodiam atque Lyciam, Perediam et Perbibesiam (the places listed by the parasite).

9 E.g. Pl. Cur. 162-163: PL. ubi tu's qui me convadatu's Veneriis vadimoniis?/ sisto ego tibi me et mihi contra itidem ut sistas suadeo; Vid. 89: defaenerare hominem egentem hau decet.

10 Stein (1971: p. 605).

11 If we speak about compound words in Plautus, we may notice that the adjectives "far outnumber the others" - Stein (1971: p. 598). 
The first example I wish to present comes from the comedy Curculio (vv. 27-32):

\author{
PA. (...) \\ ita tuom conferto amare semper, si sapis, \\ ne id quod ames populus sciat, tibi sit probro. \\ semper curato ne sis intestabilis.
}

PH. quid istuc est verbi? PA. caute ut incedas via:

quod amas amato testibus praesentibus. ${ }^{12}$

['PAL. If you're smart, always handle your love in such a way that if the people know the object of your love it isn't a disgrace for you. Always make sure you can call on someone to testify. PHAE. What do you mean?

PAL. Tread carefully on your road: love what you love in the presence of your testifiers.' $]^{13}$

Here the slave Palinurus offers some advice to his master, Phaedromus, but his speech has a kind of formal, legal tone (cf. the imperatives and the word probrum, a "disgrace, ignominy") $)^{14}$ and it seems as if it is spoken by a counsellor. The slave recommends that the young man should not be intestabilis. ${ }^{15}$ This is a word which in a legal context means a "man disqualified from calling witnesses, shameful" - OLD (Lex XII; Hor. S. 2, 3, 181; Gaius Inst. D. 28, 1, 26; Ulp. D. 28, 1, 18, 1). The etymology of the above-mentioned adjective suggests that it could be connected with the noun testis, a "witness", ${ }^{16}$ but the adulescens, reacting to the slave's statement, formulates a question which shows that he sees some incoherence between the word intestabilis and the whole utterance. In his opinion the word under discussion may be associated with the other word testis, understood as a "testicle" (Lucil. 281; Hor. S. 1, 2, 45; Priap. 15, 7). The adjective intestabilis would then gain a new meaning, namely that of a "castrated man". ${ }^{17}$ This conclusion may be drawn from the second semantic layer of the slave's utterance: he advises his young master how to handle love affairs and women - i.e. he must have in mind the punishment of castration as foreseen in Roman $\operatorname{law}^{18}$ and inflicted by the injured husband for adultery. ${ }^{19}$

12 Text: Lindsay (1910).

13 If not noted otherwise, the translation of the comedies is as per the edition: De Melo (2011, 2012, 2013).

14 The future imperatives (conferto, curato, amato) resemble the forms included in Roman legal regulations. Watson thinks that such imperatives were characteristic of the aedile edicts (Watson 1991: p. 333). About probrum, cf. e.g. D. 50.16 .42 (Ulpianus 57 ad ed.): "probrum" et obprobrium idem est. probra quaedam natura turpia sunt, quaedam civiliter et quasi more civitatis. ut puta furtum, adulterium natura turpe est: enimvero tutelae damnari hoc non natura probrum est, sed more civitatis: nec enim natura probrum est, quod potest etiam in hominem idoneum incidere.

15 A similar adjective, intestatus means "without having made a will, without having called a witness" (since Lex XII tabularum).

16 Walde \& Hofmann (1938: p. 676), s. v. testis ${ }^{1}$. Cf. Isid. orig. 10, 135: intestabilis, cuius testimonium non valet.

17 Wright (1993: p. 52); Urbanová \& Poláčková \& Weissar \& Černoch (2019: p. 140). An interesting translation is given by Przychocki, who translates intestabilis in Polish as "oświadczony", which refers to the law and to love as well, although it hides the sexual meaning of the wordplay (1937: p. 97).

18 Fredershausen (1912: p. 215); De Melo (2011: p. 233).

19 Cf. Gell. 10, 23, 4 (Verba Marci Catonis adscripsi ex oratione, quae inscribitur de dote, in qua id quoque scriptum 
Thus the semantic neologism (exactly a neosemantism ${ }^{20}$ ) emphasises the features of the stock character of a reckless adulescens amans. The meaning of intestabilis as "having no testicles" is also confirmed in line 32 which states: amato testibus praesentibus, which may be understood as: "love what you love in the presence of your testifiers" or "love, not losing/ (or exactly) still having your testicles". ${ }^{21}$ Consequently, we may assume that the word testis gains both meanings in this text, thereby creating a wordplay ${ }^{22}$ between a homonymic pair of words ${ }^{23}$ testis and testis (the pun is also proposed earlier in the adjective intestabilis), and this is certainly a pun made by Plautus. The question quid istuc est verbi? directly follows the adjective, focusing the audience's attention on the problematic word and suggesting its possible new meaning. Moreover, the slave's answer prolongs the wordplay, but also explains in a way the double entendre joke hidden here. ${ }^{24}$

The same question is used in the next example I wish to analyse, which comes from the comedy Epidicus (vv. 349-351): ${ }^{25}$

\section{(...) EP. quia ego tuom patrem faciam parenticidam.}

ST. quid istuc est verbi? EP. nil moror vetera et volgata verba.

'peratum ductare' †at† ego follitum ductitabo.

['EPI. Because I'll turn your father into a parenticide.

STRA. What sort of word is that?

EPI. I don't care for old and common words. People would carry a parricide off in a bag, but I shall carry your father off in a wallet.']"

est in adulterio uxores deprehensas ius fuisse maritis necare); Hor. S. 1. 2, 37-46 (vv. 45-46: accidit, ut cuidam testis caudamque salacem/ demeterent ferro...); V. Max. 6, 1, 13 (Sempronius Musca C. Gellium deprehensum in adulterio flagellis cecidit, C. Memmius L. Octauium similiter deprehensum pernis contudit, Carbo Attienus a Vibieno, item Pontius a P. Cer<en>nio deprehensi castrati sunt).

20 Heller et al. (1988: pp. 7-9) and Schippan (1992: p. 246) classify as neologisms new word formations (formative neologisms) and neosemantisms (semantic neologisms); cf. Busse (1996: p. 650); Elsen (2004: pp. 19-20).

21 See: Adams (1990: pp. 67-68).

22 De Melo (2011: p. 233) confirms that testis can mean "witness" and "testicle" in the passage in question (similarly, H. Kornhardt ThLL, vol. 7, 2, col. 2, vv. 5-9: lusum verborum). Mendelsohn (1907: p. 82) claims that an analogous wordplay may be seen in the comedy Amphitruo in the passage where Alcmene calls witnesses (the legal context is confirmed in line 806: sine modo argumenta dicat) who can confirm that she did not intend to cheat on her husband (v. 824): mihi quoque adsunt testes, qui illud quod ego dicam adsentiant. Mendelsohn says that the audience may understand testes in the erotic sense, since they know about a sexual encounter between Jove and Alcmene. The wordplay on testis - testis may also be found in: Phaed. 3, 11, 5; Mart. 2, 72, 8; Priap. 15, 4-7.

23 According to De Vaan the word testes "testicles" is a derivative from testis, a "witness" (2008, s. v. testis; also OLD; cf. Plin. nat. 11, 263; Suet. Nero 28, 1), but these words should be considered as homogenic homonyms (cf. Grodziński 1972: pp. 585-592), and that is why I think that the passage examined here contains paronomasia. About connections between the two words testis see: Katz (1998: pp. 183-217).

24 Leo (1960: p. 150). Leo gives more examples of similar Plautine explanations (1960: pp. 150-155).

25 This passage has already been briefly presented by the author, but in different contexts: when rethinking the etymology of parricida in general (Pieczonka 2012) and describing allusions to poena cullei in Plautine comedies (Pieczonka 2016). 
The servant Epidicus uses the word parenticida in his conversation with the young man Stratippocles. The latter seems surprised and confused ${ }^{26}$ on hearing the word, and so he asks right away: quid istuc est verbi? - "what kind of word is that?" The question implies that the word was obscure to Stratippocles and must have been perceived as a neologism. Its nature is confirmed by the slave's response - he says that he "does not care for old and common words" (nil moror vetera et volgata verba). ${ }^{27}$ It appears that Epidicus creates and uses a new word on purpose and openly admits that parenticida is a neologism. ${ }^{28}$ The noun parenticida, a "parent-killer," was rendered as a composition of the verb parens and the verbal suffix (-cida ${ }^{29}$ from caedere), which in its derivational structure resembles the familiar legal term parricida, confirmed by Festus as existing as early as the leges regiae $^{30}$ (leg. reg. Num Pomp. after Paul. Fest. p. 247 L.: Si qui hominem liberum dolo sciens morti duit, paricidas esto) and attested in other Plautine comedies (Ps. 362: (...) parricida! perge tu!; Rud. 651: TRACH. Fraudis sceleris parricidi periuri plenis<simus>). Most probably, parenticida is a playful allusion to the word parricida ${ }^{31}$ and it serves in the comedy to create the paronomastic wordplay: ${ }^{32}$ patrem faciam parenticidam, i.e. "I will make your father

26 Stein (1971: p. 604).

27 In Casina the expression verbum vetus refers to the well-known proverb which is changed by the character of the play - Pl. Cas. 969-973: (...) LY. Ecce autem uxor obviamst./ nunc ego inter sacrum saxumque sum nec quo fugiam scio./ hac lupi, hac canes: lupina scaeua fusti rem gerit;/ hercle, opinor, permutabo ego illuc nunc verbum vetus./ hac ibo, caninam scaevam spero meliorem fore. "This proverb (attested also in Hor. sat. 2, 2, 64) means that Lysidamus is threatened from all sides. He is changing the proverb by going towards one of the threatening alternatives" - De Melo (2011: p. 115). Cf. the proverb used in a new context in Pl. Cist. 505-506: ME. inter novam rem verbum usurpabo vetus:/ 'quod dedi datum non vellem, quod relicuomst non dabo'.

28 Such is also the opinion of Duckworth (1979: p. 297). Fontaine writes: "this coinage, which blends parens 'father' and parricida 'parricide' is perhaps intended as a calque, or a loan translation, of the Greek word татрокто́voৎ 'father killer'” (2010: p. 5).

29 Lindner (2002: p. 68).

30 According to the testimony of Isidore of Seville, parricida (Etym. 5, 26, 17: et dictum parricidium quasi parentis caedes) may originate from the word parenticida, which has been discussed above. The grammarian Priscian was of a similar opinion (Inst. 1, 33): "par paris paricida", quod vel a "pari" componitur vel, ut alii, a „patre”, - r euphoniae causa additur, sin a "patre”, $t$ in r convertitur; quibusdam tamen a "parente” videtur esse compositum et pro parenticida per syncopam et commutationem $t$ in r factum "parricida" (also Prisc. Inst. 5, 56: parricida...dicimus enim a parente et a verbo caedere). The ancient scholar is not, however, entirely sure of this etymology and points out that the basis for the first element of the compound might have been - par, pater or parens. The grammarian's thesis on parricida deriving from parenticida is, however, brought into question by the following issues: 1. Festus' indication (p. 247 L.) that the word paricidas existed in leges regiae, which dated back before Plautus' comedies; 2. the Plautine text of the play Epidicus, where the word parenticida is determined as a neologism (Pieczonka 2012: pp. 89-91; Pieczonka 2016: p. 197; similarly: Stein 1971: p. 604). Also Lindner (1996: p. 136) in his glossary suggests that parenticida is a transformation of the earlier paricida.

31 Perhaps parenticida in the line Epid. 349 is also an allusion to the neologism muricidus which appears earlier in line 333 in the statement of the young man Stratippocles (ST. vae tibi, muricide homo! CH. qui tibi lubet mihi male loqui?). Muricidus (a "mouse killer" or a "wall breaker" - Gray 1893: p. 46; Lindner 2002: p. 70) is probably a term of abuse (OLD, s. v. muricidus), defined as "coward, idiot, lazybones" by Paul. Fest. p. 112L (De Melo 2011: p. 369).

32 The paronomasia is further emphasised by alliteration - and it must be noted that such a combination of paronomasia, alliteration and wordplay is characteristic of the archaic poets. Cf. Wölfflin (1933: pp. 225-281). 
a parent-killer". The word parenticida is the crucial element of the utterance and it comes

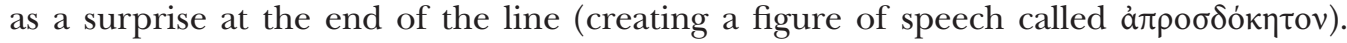
The question about this neologism is answered by the slave's statement, which confirms the novelty of the word and then offers further explanation. Parricida, a "murderer of a near relation, especially of a parent" was sewn into a sack (culleus, though here this sack is called pera, as the text mentions someone peratum) $)^{33}$ and the criminal was then drowned. Parenticida is "a comic formation, but it has a similar meaning; and the form of punishment is of course also comic", ${ }^{34}$ as a parent-killer will be imprisoned in a money bag or a wallet (follitus) ["Plautus is not concerned whether the details of such images are realistic"]. ${ }^{35}$ This humorous explanation contains two more neologisms: peratus ("done up in a food bag") and follitus ("enclosed in a money-bag"), which allude to the penalty of the sack, poena cullei, administered for the crime of parricide by Roman law. ${ }^{36}$ The slave's statement should be interpreted as meaning that while others may rob the father of food, he will rob the young man's father of money (a typical comic motif). This riddle-like explanation extends the joke far beyond the point of the newlycoined noun parenticida and helps the audience understand the intended meaning of the paralegal neologism. Parenticida is the most noticeable element in the text thanks to several markers, which are: the question, the comment about his contempt for the oldfashioned words, and the explanation about the punishment, which also contains comic neologisms. These new words are without any doubt Latin, although the adjective peratus might have been created under the influence of the Greek word $\pi \dot{\eta} \rho \alpha$, "a leather bag for keeping food" (Hom. Od. 13, 437; Ar. Pl. 298), present in the original text. ${ }^{37}$ But even if this is the case, the passage was reworked by Plautus, who added the image of a father in a bag, creating associations with the Roman punishment for parricide.

The previously mentioned question Quid istuc verbist?, which highlights the neologisms in the text, is also employed in the play entitled Pseudolus (vv. 604-609):

HA. ostium pultabo atque intus evocabo aliquem foras.

PS. quisquis es, compendium ego te facere pultandi volo; nam ego precator et patronus foribus processi foras.

HA. tune es Ballio? PS. immo vero ego eius sum Subballio.

HA. quid istuc uerbist? PS. condus, promus sum, procurator peni.

HA. quasi te dicas atriensem. PS. immo atriensi ego impero.

['HAR. (to himself) I'll knock at the door and call someone out.

33 It must be emphasised that there is a possibility that the passus originated from Greek, which could be confirmed by the use of the adjective peratus in line 351 .

34 De Melo (2011: p. 371).

35 Fränkel (2007: p. 44).

36 Leges regiae introduced by Romulus and Numa Pompilius, are thought to regulate the matter of parricide (Cf. Plut. Rom. 22, 4; Fest. p. 247 L), but the punishment of the sack is mentioned for the first time in the plays of Plautus (Epid. 349-351; Ps. 209-214; Vid. frg. 12).

37 Fränkel suggests that the passage was developed by Plautus (Fränkel 2007: p. 18). 
PSEU. (approaching him) Whoever you are, I want you to dispense with knocking: I've come forward as intercessor and patron for the door.

HAR. Are you Ballio?

PSEU. No, rather I am his Under-Ballio.

HAR. What sort of word is that?

PSEU. I'm the getter-in and giver-out, the superintendent of supplies.

HAR. As if you were calling yourself the majordomo.

PSEU. No, I give commands to the majordomo.'] transl. W. De Melo vv. 607-608:

['HARP. (looking him over disapprovingly) Are you Phallio?

PS. No, no, but in me you see his Sub-Phallio.

\section{HARP. That meaning what?}

PS. I am the butler, the factotum, the proctor of supplies.'] transl. M. Fontaine

The passage contains a conversation between Harpax, the soldier's servant, and the young man's slave named Pseudolus. In this scene Harpax appears in the pimp's house with money and a letter from the soldier with which he wants to buy a girl from the pimp Ballio. Pseudolus pretends to be Ballio's butler, because he hopes to deceive Harpax and collect the money from him. To make himself more reliable Pseudolus calls himself Subbalio, meaning "Under-Ballio", suggesting that he comes second in the household hierarchy, ${ }^{38}$ right after the master of the house. This facetiously coined new noun raises a question from Harpax: quid istuc verbist?, "What sort of word is that?" Pseudolus tries to clarify the expression, giving examples of the roles he performs in the house: condus, promus sum, procurator peni, "I'm the getter-in and giver-out, the superintendent of supplies". However, the explanation does not end here, as Harpax wants to make sure that he understood everything correctly, ergo he states: quasi te dicas atriensem. Pseudolus denies being a majordomo, "a servant in charge of household administration" ${ }^{39}$ boasting that his position is higher in the hierarchy - he claims that he "gives commands to the majordomo" (immo atriensi ego impero).

If we look at the structure of this conversation, it resembles the previous two. It consists of three parts: the neologism, the question and the explanation, which is much longer, thereby not only extending the neologistic joke, but also allowing for the accentuation of the typically comic situation between the two stock characters of a clever and a stupid slave.

Subbalio, the neologism in question, has already been a subject of interest and inquiry for scholars. For instance, David Bain thinks that subBallio (his spelling) should be understood as a professional title, meaning "a kind of deputy functionary" 40 and he puts this

38 "Sub denotes a position lower than or beneath something, an assistant", OLD, s. v. sub. Lorenz writes something similar about the word Subnero (1876: p. 154, n. 586): "Tertullian de pall. 4 nennt den Domitian Subnero 'einen zweiten Nero'”. Cf. also the verb subservire - Pl. Men. 766-767: ita istaec solent, quae viros subservire/ sibi postulant, dote fretae, feroces; Am. arg. II 4: Habitu Mercurius ei subservit Sosiae.

39 OLD, s. v. atriensis; cf. Pl. Cas. 462; Poen. 1283.

40 Bain (2001: p. 70). 
word among other similar titles which begin with sub: ${ }^{41}$ subvilicus, subpromus, ${ }^{42}$ subcustos. ${ }^{43}$ On the one hand, the scholar suspects that subBallio could reflect the Greek compound $\dot{v} \pi \circ \beta a \lambda \lambda i \omega v$, while on the other he states that the whole utterance, beginning from line $606^{44}$ is a Plautine cluster, ${ }^{45}$ and was not taken from a Greek original. August Lorenz suggests that the noun Subballio is a comic formation similar to sublingulo, an "underdish-licker', "a humorous term for a kitchen slave" ${ }^{46}$ mentioned in line 893 of the same comedy (Ps. 892-893): ${ }^{47}$

\section{(...) BA. em, subolem sis vide! \\ iam hic quoque scelestus est coqui sublingulo.}

['BAL. There, do look at the young imp! This under-dish-licker of the cook is also a crook already.']

Furthermore, Lorenz considers the titles precator, condus, promus mentioned by Pseudolus in line 608 as belonging to the slave's jargon ${ }^{48}$ and his assumption is later shared by Malcolm M. Willcock: "condus promus this looks like slave's slang referring to household tasks; 'I am the putter away and bringer out'". ${ }^{49}$ The Oxford Latin Dictionary says under the entry Subbalio that this word contains some kind of a "pun on some unidentified word". Interestingly, Michael Fontaine undertook the task of finding this unidentified word. In the passage discussed above, the scholar suspects a double entendre joke invoked by the name of the pimp (it was Ludwig Gurlitt who first sensed a hidden innuendo here) ${ }^{50} \mathrm{He}$ interprets Subbalio as "Sub-Phallio", a "lieutenant Phallio"51 or "Under-Phallio", which ironically implies that the pimp Ballio, called Phallio by Fontaine, pedicates the slave. Furthermore, the scholar thinks that condus might have been pronounced connus, which makes a pun on cunnus "a pussy", and in his opinion both terms condus and promus refer

41 Lorenz (1876: p. 160, n. 824) also thinks that suppromus, subcustos and Subbalio are comparable wordformations.

42 Also: Pl. Mil. 825: eho tu, sceleste, qui illi suppromu's: eho (Ha! You rascal ! You're his under-butler, so see here - transl. Nixon); Mil. 837: bono subpromo et promo cellam creditam!; Mil. 846: ut tibi, si promptes, alium subpromum pares (Cf. Nörenberg 1975: pp. 305-306). Subpromus = "an under wine-drawer" is a noun from promere = "to put forward", "to draw out" - Hammond, Mack, Moskalew (1968: p. 146).

43 Also Pl. Mil. 868-869: quia Sceledrus dormit, hunc subcustodem suom/ foras ablegavit (...).

44 Bain thinks that the whole utterance ends with line 614: nam haec mihi incus est: procudam ego hodie hinc multos dolos (2001: p. 70).

45 Bain (2001: p. 70); Lefèvre shares this assumption (1997: p. 121).

46 "A comic neologism, formation from sub+lingo" (OLD, s. v. sublingulo). Opelt (1965: p. 110) considers this word as a term of abuse used by the pimp Ballio to describe the cook's helper.

47 Lorenz (1876: p. 154, n. 586).

48 Lorenz qualifies precator - foribus (1876: p. 154, n. 584) and condus, promus (1876: pp. 154-155, n. 587) as being slave's jargon. Although Gurlitt sees a hidden erotic joke in the passage, he also confirms that these words belong to jargon (1921: p. 112).

49 Willcock (1987: p. 119). Similarly Lorenz (1876: p. 160, n. 824).

50 Gurlitt (1921: p. 112).

51 Fontaine (2010: p. 219). 
to pedication. ${ }^{52}$ According to Fontaine Procurator peni, a 'proctor of supplies', could be understood as a "caretaker of the penis", ${ }^{53}$ so the whole passage would "ironically imply that the duties of 'Under-Phallio' extended to the area of the personal care of his master Phallio". ${ }^{54}$ Earlier, Niall W. Slater ${ }^{55}$ had already suspected that Subbalio may suggest an effeminate slave, but Geoffrey Arnott rejected this hypothesis, writing in his review of Slater's book: "there is (...) little reason to suspect an homosexual innuendo in the coinage Subballio at Pseud. 607". ${ }^{56}$ The text itself does not give any more clues as to whether Fontaine's theory is right - in lines Ps. 689-690 the slave admits that he had lied about belonging to the pimp, but his statement does not reveal the nature of this relationship:

meum mendacium, hic modo quod subito commentus fui,

quia lenonis me esse dixi. (...)

['my lie which I came up with here so suddenly, when I said I belong to the pimp']

It is true, however, that the pimp's name, Ballio (from Gr. $\beta \alpha \lambda \lambda$ iov), ${ }^{57}$ may be interpreted as $\varphi a \lambda \lambda$ ó, membrum virile. ${ }^{58}$ But even if this is so, it does not necessarily refer to the pimp's anatomy or sexual behaviour, but may rather allude metaphorically to his features of character and/or his being a pimp as well. Such a conclusion may perhaps be drawn from a fragment from a Greek comedy entitled Etruscan by Axionicus, preserved in Athenaeus (Axionicus fr. 1, 1-2 K-A = Ath. 4, 166c):

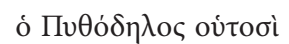

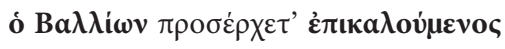

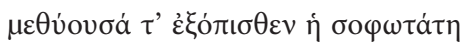

'A

['Here comes

Pythodelus, whose nickname's Big Dick;

52 Fontaine (2010: p. 219). Gurlitt suspects that the passages from Miles gloriosus which contain the word subpromus (vv. 852; 837) also refer to an erotic relationship between the two males. Moreover, the scholar thinks similarly about other derivatives from promere.

53 Fontaine (2010: p. 219).

54 Fontaine (2010: pp. 219-220).

55 Slater (2000: p. 109, n. 21).

56 Arnott (1987: p. 20 - a review of the book by Slater published in 1985). The scholar also compares the word Subbalio with subparasitor (Pl. Am. 515; 993; Mil. 348) which in his opinion also has no erotic meaning. The same comparison is made by Christenson (2000: p. 233), who recognises that both these neologisms have a similar meaning of being on the subordinate level.

57 But cf. also a Latin etymologising wordplay on the name Pl. Ps. 584-585a: nunc inimicum ego hunc communem meum atque vostrorum omnium,/Ballionem, exballistabo lepide: date operam modo; hoc ego oppidum admoenire, ut hodie capiatur, volo. The word exballistare is almost certainly a comic formation, it does not recur in Latin - Welsh (2009: p. 95).

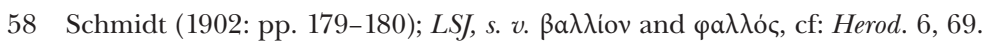


and behind him, drunk, the clever

Apotumpanischas is dogging his steps.'] ${ }^{59}$

This fragment mentions the name Ballio as a nickname, meaning "Big Dick", and the person called by this name is probably a pimp, because his companion Apotumpanischas ("Dried Fig" = "Sweetie") seems to be a prostitute. ${ }^{60}$ In Latin, the pimp's name Ballio became a synonym of "a scoundrel, worthless person" (OLD, cf. Cic. Rosc. 20; Phil. 2, 15), which might be a similar meaning to "Big Dick", but this metaphorical understanding of the name was perhaps influenced by the Plautine comedy, not the Greek nickname. Nevertheless, the word Subballio in the Plautine play is not a name or even a nickname, but a function / title of sorts, because the slave gives his fictional name later in the conversation with Harpax (Ps. 636-637):

\section{HA. (...) \\ sed quid est tibi nomen? PS. servos est huic lenoni Surus, \\ eum esse me dicam. Surus sum. HA. Surus? PS. id est nomen mihi.}

['HAR. But what's your name?

PSEU. (aside) The pimp has a slave called Syrus, I'll say that I'm him. (aloud) I'm Syrus.

HAR. Syrus?

PSEU. That's my name.']

The slave explains the word Subbalio, giving some examples of his duties. ${ }^{61}$ As I have said before, Fontaine interprets these terms as erotic (thus following Gurlitt's hypothesis on this matter $)^{62}$ and is especially suspicious of condus, a "putter-in man", a neologism not found elsewhere and used by Plautus instead of condittor, which was attested in wordplay in Epidicus (522-523: (...) qui omnium/ legum atque iurum fictor, conditor cluet) ${ }^{63}$ However, the word cunnus, "the female pudenda", indicated by Fontaine, was not used by Plautus either (attested only since Catullus), maybe because it was considered extremely obscene. ${ }^{64}$ The second title that is mentioned, promus, "the taker-out man" ("a servant who dispensed household stores, especially food and drink" - $O L D$ ), was quite a common word, and was also used by Plautus in other plays (Trin. 81: ne admittam culpam, ego meo sum promus pectori; Poen. 716: edepol fecisti prodigum promum tibi). Fontaine gives practically no evidence that it might have a sexual meaning in the Plautine play. The last expression employed by the slave, procurator peni, a "proctor of supplies", was used instead of penator. Fontaine proposes

59 Olson (2006: p. 299). A Polish translation of the passage says very boldly: "oto Pythodelos/ nadchodzi zwany Kutasem, a za nim,/ krok w krok podąża pijana Ischada,/ co umie pięknie grać na tamburynie” Danielewicz (2010: p. 360).

60 Olson (2006: p. 299).

61 Tierney considers the positions mentioned in Pseudolus as referring to ordinary offices in a small household (1943/44: pp. 173-174).

62 Gurlitt (1921: p. 112).

63 The line is in iambic senarius and the medium syllable in conditor may contain a short or a long " $\mathrm{i}$ ".

64 Loch (2019: p. 44). 
that we understand this title as a 'caretaker of the penis' against the meter (in trochaic septenarius the penultimate syllable should be short $)^{65}$ - Pseudolus would then be saying not pĕni, but pēni. However, Plautus never uses the word pēnis or penator in his plays, whereas he employs the word penus, penoris, "food, provisions", in a number of passages, and also in the comedy Pseudolus. At the beginning of the play, the pimp Ballio says (Pl. Ps. 178):

nisi mihi penus annuos hodie convenit, cras poplo prostituam vos

['unless a year's provisions come in to me today, I'll prostitute you to the common people tomorrow']

The same expression is also used later (Pl. Ps. 228-229):

nisi hodie mi ex fundis tuorum amicorum omne huc penus adfertur, cras Phoenicium poeniceo corio invises pergulam

['unless I'm brought your whole keep here today from the estates of your boyfriends, Phoenicium, you'll go to the common brothel tomorrow, with a hide that's Phoenicia purple.']

It is therefore possible that Pseudolus is alluding to the words used earlier by the pimp while he is pretending that he is Ballio's servant. Nevertheless, the allusion to the unvoiced word pēnis may be hidden in his statement anyway and might have been recognised by the audience (such relation between two similar words pĕni and pèni may be called homoionymy and a wordplay between them is a paronomasia).

It is worth noticing that the whole passage contains more names of positions than those listed by Fontaine - line 606 mentions precator et patronus foribus, "intercessor and patron for the door", ${ }^{66}$ and line 609 contains the word majordomo, atriensis. The scholar does not describe them, nor does he mention them as having any erotic meaning. However, it must be admitted that the door, fores=ianua, may have had a sexual meaning of the "external female pudenda" or an "anus" ${ }^{67}$ Therefore, the noun atriensis, which refers to someone who guards the door of the household, might also be understood in the erotic sense. This may be confirmed by the passage from another Plautine play, Casina (vv. 459-463):

OL. ultro te, amator, apage a dorso meo!

CH. illuc est, illuc, quod hic hunc fecit vilicum.

et idem me pridem, quom ei advorsum veneram,

facere atriensem voluerat sub ianua.

OL. ut tibi morigerus hodie, ut voluptati fui.

['OL. Away with you, lover, get off my back!

65 Questa (2007: p. 355).

66 The slave "says comically that he has come out (processi foras) to intercede on behalf of the door" - Willcock (1987: p. 119).

67 Adams (1990: p. 89); De Melo (2011: p. 60). 
CHAL. That's it, that's why he made him overseer. And some time ago, when I'd come to meet him, he also wanted to make me the doorkeeper down by the back entrance.

OL. How submissive I've been to you today, how much pleasure I've given you!']

In the above scene, it is implied that the slave "Olympio got his job as vilicus by submitting sexually to the master", ${ }^{68}$ senex Lysidamus. Homoerotic relation between these two characters is suggested by the expressions: apage a dorso meo; morigerus ${ }^{69}$ and voluptati fui $^{70}$ The second slave, Chalinus, says that he had been given a similar proposition ${ }^{71}-$ he could become atriensis in exchange for homosexual services, which are implied by the noun ianua (a "back entrance," meaning metaphorically an "anus"). But even though the noun atriensis may be interpreted in Casina as erotic, this fact does not definitely determine the meaning of this particular word in the comedy Pseudolus.

Therefore, all things considered, it is difficult to judge whether Fontaine's theory is right - there are arguments for and against it. Moreover, Fontaine's hypothesis seems to be contradicted by the general sense of the whole scene in question (Ps. 604-609). The eponymous slave is a servus callidus who has just come up with a new trick and he seems to be boasting about his new fictionally assigned position in the house of the pimp. His exemplification is to prove that he really works here and that he can be trusted with the money that Harpax has brought. It would be weird to assume that he explicitly admits to being Ballio's boy, a submissive homosexual partner, when he wants to present himself as a reliable second emperor of the house, to command respect and to persuade Harpax to hand over the money. The only sensible explanation for this kind of self-incrimination could be that Pseudolus, while boasting, could be unconsciously praising and humiliating himself at the same time (which would be very ironic).

Regardless of this controversy, we may admit that the passage from Pseudolus represents a scheme of a neologism depiction analogous to the two that were mentioned earlier in this paper, where the newly coined word and the subsequent question are followed by a riddle-like explanation. Subballio differs from the first two examples of neologisms only in the fact that it may be deciphered as a hybrid, composed of a Latin prefix sub- and a Greek name Ballio (Ba $\lambda \lambda$ iov), while the first two are Latin word-formations.

The last neologism I would like to include in my article is derived from the Greek word arrabo (ó ả $\rho \rho \beta \omega \dot{\omega} v),{ }^{72}$ which means a "pledge/money which in purchases is given as a pledge that the full amount will subsequently be paid". In the passage from the comedy Truculentus, the eponymous slave wishes to rent the courtesan's maid named Astaphium for the night, and therefore he gives her an advance for her service, but he mentions the word arrabo in an odd shortened version (Truc. 687-690):

68 O’Bryhim (1989: p. 98).

69 This adjective is usually used to describe women - O'Bryhim (1989: p. 98).

70 See also earlier Pl. Cas. 455: credo hercle ecfodere hic volt vesicam vilico.

71 Craig (2010: pp. 37; 322, n.131).

72 Frequently also written ảpaßív. Latin authors also used an abbreviated form $\operatorname{arr}(h) a$ (Plin. Nat. 29, 21; 33, 28; Gell. 17, 2, 21), which according to Hamp (1985: p. 109) arose as a shortening in mercantile slang. 
(...) TR. tene hoc tibi:

rabonem habeto, uti mecum hanc noctem sies.

AS. perii! 'rabonem'? quam esse dicam hanc beluam?

quin tu 'arrabonem' dicis? TR. 'a' facio lucri,

ut Praenestinis 'conea' est ciconia.

['TRUC. (handing over his wallet) Take this: have it as a posit, so that you'll spend the night with me.

AST. I'm dead! "Posit"? What beast should I say this is? Why don't you say "deposit"? TRUC. I'm saving the “de", just as a woodpecker is a "pecker" for people of Praeneste.']

The word in question is transformed by the slave, who decides to cut off the beginning letter "a" and take it as his savings ( 'a' facio lucri). Such a poetic device of separating the word into two parts, called divisio or tmesis ( $\tau \mu \tilde{\eta} \sigma \iota \varsigma)$, has been known and used in Latin literature since Ennius, ${ }^{73}$ but the maid from the Plautine play is surprised at hearing the strange new word, which she describes as belua ${ }^{74}$ "the beast". The slave confirms the comic device, presenting another example of such a linguistic phenomenon. He claims that the inhabitants of Praeneste do the very same thing - instead of ciconia they use the abbreviated form conea. Wallace Lindsay tried to translate the noun rabo, coined by Truculentus, as a "raver", ${ }^{75}$ as if this word would be derived from the verb rabio rabere, "to rave", "to be frenzied with rabies" $(O L D)$. Unfortunately, the scholar was mistaken, because rabo is certainly a mutilated form of arrabo, a word which came into Latin from the Greek, ${ }^{76}$ but earlier it seems to have passed to Greek from the Hebrew ${ }^{77} \bar{e} r \bar{a} \underline{b} \bar{n} n$ (pre-

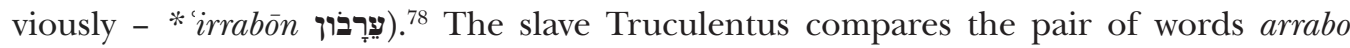
- rabo with the Latin ciconia and Praenestine conea, suggesting that conea is a derivative from ciconia. ${ }^{79}$ It seems likely that the Praenestine dialect probably tended to leave out vowels, ${ }^{80}$ so that the word ciconia could have been reduced by the process of haplology

73 Cf. Enn. spuria fragmenta 13 W.: saxo cere comminuit brum; Enn. spuria fragmenta 44 W.: Massili portabant iuvenes ad litora tanas. Warmington considers these fragments spurious (1935: pp. 450, 464); Zetzel suspects that Ennius, using the device of divisio, might have imitated Homer (1974: pp. 137-140).

74 Fontaine (2004: pp. 149-150) states that in the passage from Plautine Aulularia employs the word belua in an analogous way (vv. 561-564): (...) EUCL. Quo quidem agno sat scio/ magis curionem nusquam esse ullam beluam./ MEG. Volo ego ex te scire qui sit agnus curio./ EUCL. Quia ossa ac pellis totust, ita cura macet. Cf. belua in Plautine comedies translate de homine Poen. 347; Most. 607; Rud. 886; Trin. 952.

75 Lindsay (1894: p. 177).

76 Varro gives such an explanation (L. 5, 175): hoc verbum arrabo... a graeco ả $\rho \alpha \beta \omega ́ v$. A false etymology of arrabo is given by Isidore of Seville (Orig. 9, 7, 5): arrabo dicta quasi arra bona. Arrabo is also a river in Pannonia, nowadays called the Raab (F. Vollmer, ThLL II, col. 633, vv. 66-75).

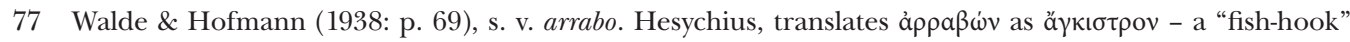
(cf. Chantraine 1968: p. 115, s. v. ả $\rho \rho \beta \omega \dot{v}$ ).

78 Cf. Genesis 38, 17-18; 2 Corinthians 1, 5 ; 2 Corinthians 1, 22; Ephesians 1, 14; Isaiah 8, 20; cf. Arist. Pol. 1259a12; Plu. Galb. 17.

79 According to De Vaan "the reduplication [in ciconia - JP] is probably a part of the onomatopoeic formation, as in cicada a cricket" (De Vaan 2008: p. 113, s. v. ciconia); "ciconia a "stork" is a bird also characterized by its clappering sound" (De Vaan 2008: p. 112, s. v. cicada).

80 Lindsay writes about a syncope in the Praenestine dialect of Latin e.g. Dcumius (for Dĕcŭmius - CIL I, 
to [c-conia], which eventually would produce conia. ${ }^{81}$ However, it also looks like Plautus intended "to make fun of the way the Praenestines pronounce certain words", ${ }^{2}$ and that is why he allowed the rustic slave ${ }^{83}$ (he is called agrestis in Truc. 253) ${ }^{84}$ to use this dialectal form of Latin. ${ }^{85}$ The humorous and rustic tone of the slave's utterance can be inferred from his earlier words (Truc. 682-686):

\section{$T R$. heus tu! iam postquam in urbem crebro commeo, \\ dicax sum factus. iam sum caullator probus. \\ AS. quid id est, amabo? istaec ridicularia; \\ cavillationes vis opinor dicere? \\ TR. ita, at pauxillum differt a cavillibus.}

['TRUC. Hey you! Now that I come into town often, I've become witty. Now I'm a decent stalker.

AST. What's that, please? Stop your jokes; I believe you want to say "talks"?

TRUC. Yes, but there's little difference from "stalks".']

In this dialogue the slave admits that he comes from the country and his incorrectly spoken words are called jokes (ridicularia) by the maid Astaphium. This passage is directly followed by the lines which contain the invented neologism rabo and the Praenestine form conea, so these words may also be perceived as comic formations made up by a peasant (their purpose is to emphasise the slave's rustic features). The neologistic nature of the word rabo is confirmed by the maid, who describes it as belua. The passage about ciconia - conea is a kind of explanation of the word-derivation process. We may only wonder why Plautus used the word arrabo, although he could have employed the Latin pignus instead ${ }^{86}$

1133); (...) Diesptr (for Diēspüter - CIL I, 1500); Ptronio (for Pĕtrōnio) - Lindsay (1894: p. 177). The scholar says that the syncope might be a result of the antepaenultima accent, but in some words it seems that the accented syllable is omitted, e.g. Trtia (for Tertia - Eph. I, 108); Atlia (for Atilia - Eph. I, 33). Cf. De Melo (2013: p. 345). Adams claims that: "It may be concluded that the town had a dialect to Roman ears (...), but to what extent it shared non-urban phonology with other areas of Latium and nearby cannot be determined" (2007: p. 123). However, it seems that the Latin spoken in the city was different from the variety spoken in the country and it could be the subject of mockery (Lucil. frg. 1130: ne Cecilius pretor fiat rusticus) - Adams (2007: p. 118).

81 Karakasis (2005: p. 7).

82 Karakasis (2005: p. 7).

83 O. Prinz concludes that the form rabo is also rustic (ThLL II, col. 633, vv. 9-10).

84 Truculentus also sounds rustic in Pl. Truc. 276-279: (...) ita me amabit sarculum,/ ut ego me ruri amplexari mavelim patulam bovem/ cumque ea noctem in stramentis pernoctare perpetim,/ quam tuas centum cenatas noctes mihi dono dari.

85 Festus gives a few examples of a Praenestine language: Fest. 162, 19-21: . . <testicul>os, quos Lanu/<vini

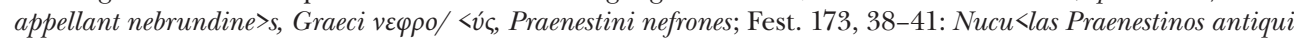
appellabant,>/ quod inclusi a <Poenis Casilini famem nucibus sustenta>/verunt: vel quod in e<orum regione plurima nux minu>/ ta nascitur; Fest. 351, 9-13: Tongere Aelius Sti>lo ait noscere esse,/ <quod Praenestini tongi>tionem dicant pro no/ <tionem . . la lius dominari; Ennius:/ . . <alii rhetorica> tongent; et vincere/. . . videtur significare.

86 Cf. Hier. epist. Eph. 1,14: pignus Latinus interpres pro arrabone posuit. non id ipsum autem arrabo, quod pignus sonat. arrabo enim futurae emptionis quasi quoddam testimonium vel obligamentum datur. 
- the interesting thing is that both these terms may be found in his comedies (arrabo: ${ }^{87}$ Mil. 957; Mos. 645; Rud. 46; 555; 861; but v. 581 pignus). ${ }^{88}$ I suppose that Plautus might have translated a Greek passage here. Splitting the prefix $a$ (e.g. expressing want, absence or strengthening the meaning) from the main word seems like a Greek linguistic process, although it should concern compound word-formations, to which arrabo does not belong. The proof of the Greek provenience of the passage may be hidden in the

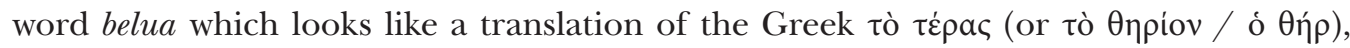

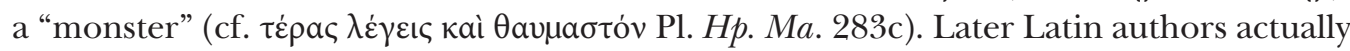
used the word monstrum ${ }^{89}$ to describe a strange, incredible statement or an odd word, as we may conclude from the passage of Gellius' Noctes Atticae (11, 7, 9, 1):

atque id uoce magna ter quaterue inclamauit: 'bouinator est'. Commurmuratio fieri coepta est a plerisque, qui aderant, quasi monstrum uerbi admirantibus.

['and then three or four times, with a loud voice, he bawled out the word bovinator. A whispering took place among some who were present, wondering at this monster of a word.' $]^{90}$

The pun on ciconia - conea seems to have been created by Plautus, as it concerns Latin words. Nevertheless, I wonder if this joke could also imitate the verbal humour from the Greek original. It is very intriguing that the Greek word for a stork, ò $\pi \varepsilon \lambda \alpha \rho \gamma$ ó, can be separated as well. First, if we split $\pi \varepsilon \lambda \alpha \rho \gamma$ ó, , which literally means "black and white", ${ }^{91}$ we

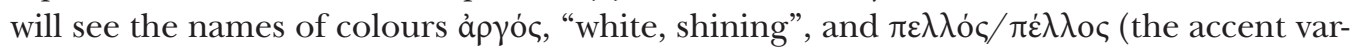
ies in codd. LSJ), "dark coloured, dusky". Then, if we cut off the first part $\pi \varepsilon \lambda$-, we will be

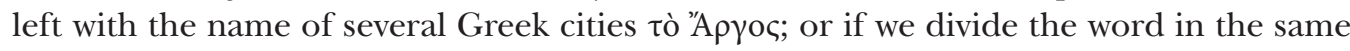

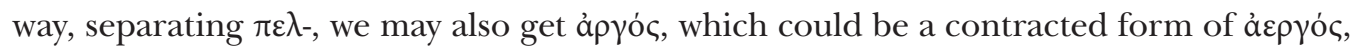
"not working" - this word, when referred to money, may mean "lying idle, yielding no return" (LSJ), so it could define a pledge. Of course, these are all guesses, but the notion

87 Terence uses arrabo only in: Haut. 603; the word is not attested in Cicero (Maltby 1985: pp. 113; 118).

88 Plautus repeatedly uses Greek legal terms and their Roman equivalents interchangeably, e.g. damnum,

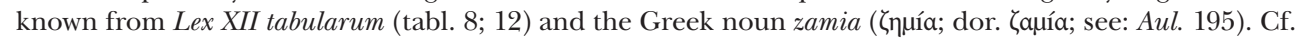

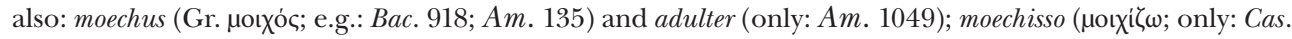
806) and adultero (only: Bac. 268). In the comedy Casina the word moechisso appears next to adulterium in

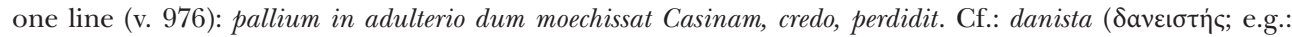
Epid. 55; 607; Mos. 537; 623; Ps. 187) = faenerator (only: Mos. arg. 6; cf. faeneratrix). Other Greek-Roman

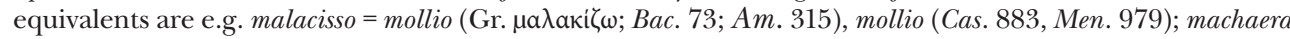

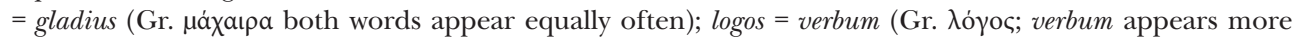

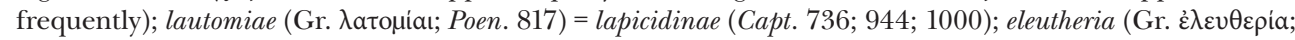
Per. 29a; St. 422) = libertas (the noun appears many times in Plautine comedies, e.g.: Am. 650; Bac. 168;

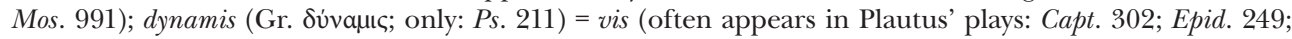

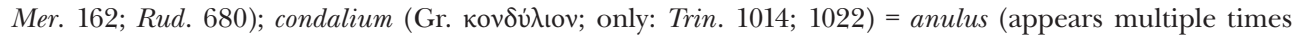
in the plays, e.g.: As. 778; Cas. 144; Cur. 356; Vid. 105). The examples after: Weise (1882) and Lodge (1904-1924; 1926-1933).

89 Also: Lucr. 4, 591: Cetera de genere hoc monstra ac portenta loquuntur; Cic. 4. Tusc. 24, 54: Remove perturbationes, maximeque iracundiam: iam videbuntur monstra dicere; Cic. Att. 4, 7: Venerat horis duabus ante Chaerippus: mera monstra nuntiarat.

90 Beloe (1785: p. 290).

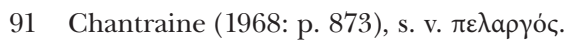


of Greek wordplay being present in the passage seems quite appealing to me. Plautine originality would lie in translating the divisio joke, finding the Latin equivalent belua and rendering the Greek wordplay for the Roman audience. Nevertheless, regardless of the provenience of the Latin pun ciconia - conea (if it continues the Greek wordplay on $\pi \varepsilon \lambda \alpha \rho \gamma o ́ \varsigma)$, we must admit that it was certainly composed as an explanation of the neologism rabo and was done especially for the Roman spectators.

\section{Conclusion}

In conclusion, we need to state that all the neologisms analysed here were made up by slaves, who used this linguistic device to underline the representation in the play of such elements of the world as stock characters (adulescens amans, servus callidus and stupidus) and motifs (deceiving a senex and robbing him of money; playing a trick on leno). Among these word-formations are three nouns and one adjective. The first two examples try to bring the etymology of the new "funny" words closer, juxtaposing them with their alleged formative bases (intestabilis - testibus praesentibus; patrem faciam parenticidam), while the noun in the last passage shows the process of word-derivation called divisio (arrabo - rabo). If we want to consider the originality of the neologisms presented here, we may notice that intestabilis and parenticida are Latin compound word-formations, Subballio is probably a hybrid, and rabo is in fact a Greek neologism transcribed into Latin. Regardless of these differences, in all of these cases the playwright employs a particular kind of utterance structure: each begins with a humorous neologism, followed by a question about its meaning and then the explanation of the incomprehensible word. The characters in the plays, by asking for an interpretation of the strange invented words (quid istuc est verbi?) or making some comments about them (vetera et volgata verba / belua), draw attention to their neologistic nature. They "signpost these creations for us" 92 and of course for the Roman audience too. Neologisms do not conform to standard knowledge of lexems, and that is why they may need some explanation from the interlocutor who is using them for the first time. Three of the passages discussed above concern legal neologisms (intestabilis, parenticida, rabo), which may be more difficult to understand when used in comic contexts in place of legal ones. That is why Plautus expands the dialogues in the scenes analysed above in order to clarify the new word-formations and to compound the joke. The explanation that follows each new word is in fact a variation on the preceding words, a playful elaboration of the subject which usually contains a riddle to solve (sometimes in the form of new neologisms). Eduard Fränkel calls this kind of a dialogue structure an identification motif ${ }^{93}$ and recognises this device as peculiar to Plautus. ${ }^{94}$ Fränkel

92 Fontaine (2010: p. 5).

93 Fränkel (2007: pp. 17; 28-29) - the whole chapter is on this motif (Fränkel 2007: pp. 17-44).

94 Terence, according to Fränkel, “offers nothing of this kind nor, apparently, does Menander” (Fränkel 2007: p. 19). "Similar things occasionally appeared in the Attic comedies, though hardly in Menander, where even similes, the weaker form of identification, are hard to find (this is in contrast to Old and Middle Comedy)" - Fränkel (2007: p. 38; cf. also pp. 39-41). 
notices that "in Greek comedy real comparisons predominated, not the identifications so beloved by Plautus". ${ }^{95}$ The Plautine identification motif may be pictured as a composition of two elements joined by the verb "to be" = "a" is "b". ${ }^{96}$ All the passages presented above contain such typical Plautine riddling identifications, despite the fact that not all the neologisms under consideration are Latin. Plautus decides to develop the dialogues which contain these neologisms not only to clarify their meaning, but also in the process to rework a Greek text or to adapt a Greek play on words for his Roman spectators. The most important function of these identification motifs is that they intensify the power of the jokes and the impact of the verbal humour on the audience. Thanks to this fact, the new words "do not pass unnoticed". ${ }^{97}$

\section{Bibliography}

Adams, J. N. (1990). The Latin Sexual Vocabulary. London: Duckworth.

Adams, J. N. (2007). The Regional Diversification of Latin, 200 BC - AD 600. Cambridge: Cambridge University Press.

Arnott, W. G. (1987). (Rev.). N. W. Slater: Plautus on Performance. The Theatre of Mind. Gnomon, 59(1), 17-20.

Bain, D. (2001). Subvilicus, supromus, subBallio (Plaut. Pseud. 607). Zeitschrift für Papyrologie und Epigraphik, 134, 70.

Bartol, K., \& Danielewicz, J. (Eds.). (2010). Atenajos: Uczta mędrców. Poznań: Wydawnictwo Poznańskie.

Beloe, W. (Ed.). (1785). The Attic Nights of Aulus Gellius (Vol. 2). London: Printed for J. Johnson, St. Paul's Church-Yard.

Busse, U. (1996). Neologismen. Der Versuch einer Begriffsbestimmung. In M. Gellerstam, J. Järborg, S. G. Malmgren, K. Norén, L. Rogström, \& C. R. Papmehl (Eds.), Euralex '96. Proceedings I-II (Vol. 2; pp. 645-658). Göteborg: University of Göteborg.

Chantraine, P. (1968). Dictionnaire étymologique de la langue grecque. Histoire des mots. Paris: Klincksieck.

Christenson, D. (Ed.). (2000). Plautus: Amphitruo. Cambridge: Cambridge University Press.

Craig, A. W. (2010). Roman Homosexuality. New York: Oxford University Press.

De Melo, W. (Ed.). (2011). Plautus: Casina, The Casket Comedy, Curculio, Epidicus, The Two Menaechmuses (Vol. 2). Cambridge: Harvard University Press.

De Melo, W. (Ed.). (2012). Plautus: The Little Carthaginian, Pseudolus, The Rope (Vol. 4). Cambridge: Harvard University Press.

De Melo, W. (Ed.). (2013). Plautus: Stichus, Three-Dollar Day, Truculentus, The Tale of a Travelling-Bag, Fragments (Vol. 5). Cambridge: Harvard University Press.

95 Fränkel (2007: p. 38).

96 Cf. identification motifs: Pl. Poen. 609-610: (...) CO. fores hae fecerunt magnum flagitium modo./ ADV. quid <id> est flagiti? CO. crepuerunt clare.; Poen. 862-863: (...) SY. facio quod manufesti moechi hau ferme solent./ MI. quid id est? SY. refero vasa salva. (...).

97 Adams (2007: p. 120). 
De Vaan, M. (2008). Etymological Dictionary of Latin and the Other Italic Languages. Leiden: Brill. Duckworth, G. E. (Ed.). (1979). Plautus T. M.: Epidicus. New York: Arno Press.

Elsen, H. (2004). Neologismen. Formen und Funktionen neuer Wörter in verschiedenen Varietäten des Deutschen. Tübingen: Narr Verlag.

Fontaine, M. (2004). Agnus KOYPISN (Plautus Aulularia 561-564). Classical Philology, 99(2), 147-153.

Fontaine, M. (2010). Funny Words in Plautine Comedy. New York: Oxford University Press.

Fränkel, E. (1922). Plautinisches im Plautus. Berlin: Weidmann [= Elementi Plautini in Plauto (Transl. F. Munari). Firenze: 'La Nuova Italia' Editrice 1960 = Plautine Elements in Plautus (Transl. T. Drevikovsky, \& F. Mücke). Oxford: Oxford University Press 2007].

Fredershausen, O. (1912). Weitere Studien über das Recht bei Plautus und Terenz. Hermes, 47, 199-249.

Gray, J. H. (Ed.). (1893). T. Macci Plauti Epidicus. Cambridge: Cambridge University Press.

Grodziński, E. (1972). Wieloznaczność a homonimia. Poradnik Jezykowy, 10, 585-592.

Gurlitt, L. (1921). Erotica Plautina. Eine Auswahl erotischer Szenen aus Plautus. München: Georg Müller.

Hammond, M., Mack, A. M., \& Moskalew, W. (Eds.). (1968). Plauti T. M. Miles gloriosus. London: Harvard University Press.

Hamp, E. P. (1985). Latin arr(h)a. Glotta, 63(1/2), 109.

Heller, K., Herberg, D., Lange, C., Schnerrer, R., \& Steffens, D. (Eds.). (1988). Theoretische und praktische Probleme der Neologismenlexikographie: Überlegungen und Materialien zu einem Wörterbuch der in der Allgemeinsprache der DDR gebräuchlichen Neologismen. Berlin: Akademie der Wissenschaften.

Karakasis, E. (2005). Terence and the Language of Roman Comedy. Cambridge: Cambridge University Press.

Katz, J. T. (1998). Testimonia Ritus Italici: Male Genitalia, Solemn Declarations and a New Latin Sound Law. Harvard Studies in Classical Philology, 98, 183-217.

Lefèvre, E. (1997). Plautus' Pseudolus. Tübingen: G. Narr.

Leo, F. (1960). Analecta Plautina: De figuris sermonis (Vol. 2). In E. Fränkel (Ed.), Ausgewählte Kleine Schriften (Vol. 1; pp. 123-162). Roma: Edizioni di storia e letteratura.

Lindner, T. (1996). Lateinische Komposita. Ein Glossar, vornehmlich zum Wortschatz der Dichtersprache (Innsbrucker Beiträge zur Sprachwissenschaft, 89). Innsbruck: Institut für Sprachwissenschaft.

Lindner, T. (2002). Lateinische Komposita. Morphologische, historische und lexikalische Studien (Innsbrucker Beiträge zur Sprachwissenschaft, 105). Innsbruck: Institut für Sprachen und Literaturen.

Lindsay, W. M. (1894). Latin Language. An Historical Account of Latin Sounds, Stems, and Flexion. Oxford: Clarendon Press.

Lindsay, W. M. (Ed.). (1910). Plautus: Comoediae (Vol. 1, 2). Oxford: Oxford University Press.

Loch, M. (2019). Pedicare, Studium lingwistyczno-kulturowe z zakresu seksualności starożytnych Rzymian. Poznań: Diss. [retrieved 13.04.2020 from: https://repozytorium.amu.edu.pl/bitstream/10593/24958/1/Loch\%20Marcin\%20-\%20PEDICARE.\%20Studium\%20lingwistyczno-kulturowe \%20z\%20zakresu\%20seksualno\%C5\%9Bci\%20staro\%C5\%BCytnych\%20Rzymian.pdf].

Lodge, G. (1904-1924). Lexicon Plautinum (Vol. 1). Lipsiae: Teubner. 
Lodge, G. (1926-1933). Lexicon Plautinum (Vol. 2). Lipsiae: Teubner.

Lorenz, A. (Ed.). (1876). Ausgewählte Komödien des T. Maccius Plautus (Vol. 4). Berlin: Weidmann.

LSJ = Liddell, H. G., Scott, R., \& Jones, H. S. (Eds.). (1996 $\left.{ }^{9}\right)$. Greek-English Lexicon. Oxford: Clarendon Press.

Maltby, R. (1985). The Distribution of Greek Loan-Words in Terence. Classical Quarterly, 35(1), 110-123.

Mendelsohn, C. J. (1907). Studies in the Word-play in Plautus. Philadelphia: University of Pennsylvania.

Nörenberg, W. (1975). Einige Beobachtungen zur Lucrio-Szene des plautinischen Miles gloriosus. Rheinisches Museum, 118(3/4), 285-310.

O'Bryhim, S. (1989). The Originality of Plautus' Casina. The American Journal of Philology, 110(1), 81-103.

OLD = Glare, P. G. W. (Ed.). (1996). The Oxford Latin Dictionary. Oxford: Clarendon Press.

Olson, S. D. (Ed.). (2006). Athenaeus: The Learned Banqueters, Book III, 106e-V. London: Loeb Classical Library.

Opelt, I. (1965). Die lateinischen Schimpfwörter und verwandte sprachliche Erscheinungen. Heidelberg: Carl Winter.

Pieczonka, J. (2012). Parricida a parenticida - hipoteza etymologiczna na podstawie żartu w passusie Pl. Epid. 349-351. Czasopismo Prawno-Historyczne, 64(1), 89-93.

Pieczonka, J. (2016). Punishment of the Sack - Some Evidence from Plautus' Comedies. In S. Nowicki (Ed.), "They Called Me to Destroy the Wicked and the Evil”. Selected Essays on Crime and Punishment in Antiquity (pp. 195-209). Münster: Ugarit Verlag.

Przychocki, G. (Ed.). (1937). Plautus T. M.: Komedje (Vol. 4). Kraków: Krakowska Spółka Wydawnicza.

Questa, C. (2007). La metrica di Plauto e di Terenzio. Urbino: Quattro Venti.

Schippan, T. (1992). Lexikologie der deutschen Gegenwartssprache. Tübingen: M. Niemeyer.

Schmidt, K. (1902). Griechische Personennamen bei Plautus (Vol. 1). Hermes, 37(2), 173-211.

Slater, N. W. (2000). Plautus on Performance: The Theatre of Mind. New York: Harwood Academic Publishers.

Stein, J. P. (1971). Compound Word Coinages in the Plays of Plautus. Latomus, 30(3), 598-606.

Tierney, J. T. (1943/44). The Miles gloriosus and Greek New Comedy. Proceedings of the Royal Irish Academy: Archeology, Culture, History, Literature, 49, 167-185.

Urbanová, D., Poláčková, E., Weissar, T., \& Černoch, R. (Eds.). (2019). Titus Maccius Plautus: Curculio aneb Darmojed. Brno: Bilingua.

Walde, A., \& Hofmann, J. B. (1938). Lateinisches etymologisches Wörterbuch. Heidelberg: C. Winter.

Warmington, E. H. (Ed.). (1935). Remains of Old Latin, Ennius and Caecilius (Vol. 1). London: The Loeb Classical Library.

Watson, A. (1971). The Imperatives of the Aedilician Edict. Tijdschrift voor Rechtsgeschiedenis, 39, 73-83 [= A. Watson (1991). The Imperatives of the Aedilician Edict. In A.Watson, Studies in Roman Private Law (pp. 334-343). London: Bloomsbury Academic].

Weise, O. (1882). Die griechischen Wörter im Latein. Leipzig: Fürstlich Jablonowski'sche Gesellschaft. Welsh, J. T. (2009). Balli(o)starium: Plautus, "Poenulus" 200-2. Mnemosyne, 62, 94-99.

Willcock, M. M. (Ed.). (1987). Plautus: Pseudolus. Bristol: Bristol Classical Press and Oak Park. 
Wölfflin, E. (1881). Zur Alliteration. Sitzungsberichte der Königlich-Bayerischen Akademie der Wissenschaften, 2, 1-94 [= In G. Meyer (Ed.). (1933). Ausgewählte Schriften (pp. 225-281). Leipzig: Dieterich'sche Verlagsbuchhandlung].

Wright, J. (Ed.). (1993). Plautus' Curculio. Norman and London: University of Oklahoma Press. Zetzel, J. E. G. (1974). Ennian Experiments. American Journal of Philology, 95(2), 137-140.

Dr. Joanna Pieczonka / joannapieczonka@gmail.com; joanna.pieczonka@uwr.edu.pl Institute of Classical, Mediterranean and Oriental Studies

University of Wrocław, Faculty of Philology

Komuny Paryskiej 21, 50-451 Wrocław, Poland 